\title{
黒部川流砂系における土砂動態と管理上の課題 \\ SEDIMENT TRANSPORT OF KUROBE SEDIMENT FLOW SYSYTEM AND ISSUES IN SEDIMENT MANAGEMENT
}

\author{
福濱方哉 ${ }^{1} \cdot$ 村田文人 $^{2} \cdot$ 池田敏男 ${ }^{3} \cdot$ 寺崎賢 $^{4} \cdot$ 岩見収二 ${ }^{5}$ \\ Masaya FUKUHAMA, Fumito MURATA, Toshio IKEDA, Kenichi TERASAKI, Shuji IWAMI \\ 1正会員 工修 国土交通省北陸地方整備局 黒部河川事務所長（广938-0042 富山県黒部市天神新173） \\ 2非会員 国土交通省北陸地方整備局＼cjkstart黒部河川事務所＼cjkstart建設専門官（同上） \\ 3非会員 国土交通省北陸地方整備局 黒部河川事務所 土砂管理課長（同上） \\ 4非会員＼cjkstart国土交通省北陸地方整備局＼cjkstart黒部河川事務所＼cjkstart調査・品質確保課＼cjkstart専門員（同上） \\ 5正会員＼cjkstart修（工）（株)建設技術研究所＼cjkstart東京本社河川部（†330-0071さいたま市浦和区上木崎1-14-6）
}

The Kurobe river has large amount of sediment transport, and the river channel on the Kurobe river alluvial fan and the Shimoniikawa coast that ranges to the river mouth have been formed by these sediment transport. In such the river and the coast, if the sediment transport decrease or it is interrupted by structures, excessive erosion and excessive sedimentation occur. Then problems on the management of the river and the coast are caused. In this study, the sediment transport in the Kurobe sediment flow system, composed of the Kurobe river and the Shimoniikawa coast, were understood, and issues of the sediment management were confirmed.

Key Words : Sediment transport, Sediment Flow System, Sediment management,

\section{1.はじめに}

黒部川は, $85 \mathrm{~km}$ の幹川流路延長に対し, 流域の縁辺 を3,000m級の山々に囲まれる平均勾配（源流の標高と幹 川流路延長の比） $3.5 \%$ の急流河川である. 黒部川流域 の地質は，第三紀末の脆い風化花崗岩で形成されている. また，その降水量は，仙人谷ダム地点で年平均 $4,000 \mathrm{~mm}$ を越える我が国屈指の高降水量である. 脆い地質の下, 多量の降水が急勾配地を流れることから，山地からの莫 大な流出土砂量により黒部川扇状地が形成されてきた.

黒部川扇状地の富山湾との縁境は下新川海岸である. 富山湾口が北東に開いていることから下新川海岸の卓越 波向きは北東からであり，漂砂は東から西に向かう。

このように形成されてきた黒部川流域と下新川海岸で あるが，供給土砂量の大きな河川・海岸で一旦土砂がせ き止められると, その上流側では土砂の異常堆積, 下流 側では異常侵食が発生し, 形成されてきた地形が大きく 変化する. また, 土砂を採取したり, 河口が付け替えら れるなどの土砂供給形態の変更も同様な地形変化をもた らす。

本研究は，黒部川流域と下新川海岸を一連の黒部川流 砂系として捉え，これまでに集められた土砂動態資料と
土砂動態モデルを用いて土砂動態の分析を行い, 宇奈月 ダム及びその下流の河川，並びに下新川海岸における土 砂管理上の課題を明らかにしたものである.

\section{2. 各領域の土砂動態}

土砂動態を整理するにあたり，土砂動態に影響を与え る黒部ダム, 出し平ダム, 宇奈月ダム等の主要な構造物 や最大支川黒薙川の流入, 海岸の存在を考慮し, それぞ れの特性を踏まえ，黒部川流砂系を黒部ダム上流域，砂 防領域, ダム領域, 河道領域, 海岸領域の5つの領域に 分割した. 黒部川流砂系とその領域区分を図-1に示寸.

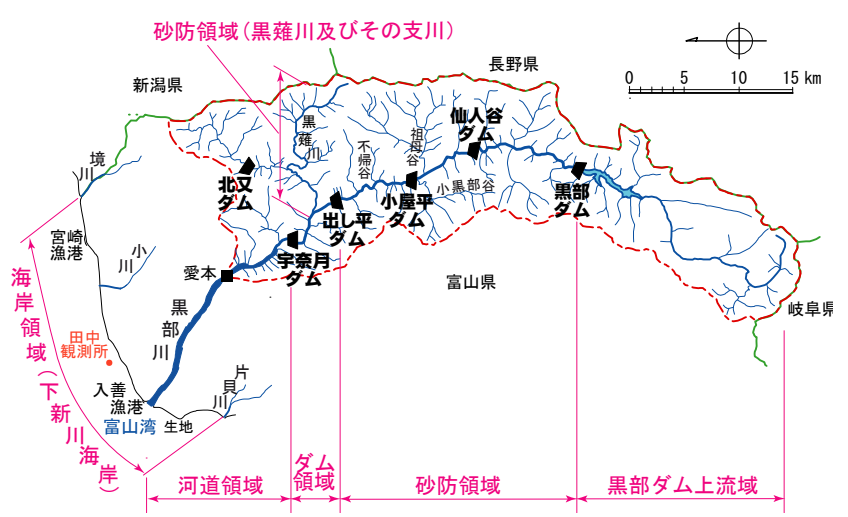

図-1 黒部川流砂系と領域 


\section{（1）黒部ダム上流域の土砂動態}

黒部ダムは，関西電力により昭和38年に建設された. 黒部ダムより上流域で発生する土砂は黒部ダムに堆積し, 下流一の供給はほとんどないものと考えられることから， 黒部ダム上流域を一つの領域として分別した。黑部ダム の総貯水容量は19,929万 $\mathrm{m}^{3}$ であり，土砂管理上，特段の 課題は顕在化していない.

\section{（2）砂防領域の土砂動態}

砂防領域は，黒部川への土砂生産・土砂流出の多い黒 部ダム下流から出し平ダムまでの区間と黒薙川及びその 流域とした．祖母谷，小黒部谷，不帰谷では大崩壊地を 形成し，黒部川への土砂供給源となっている．平成7年 洪水時には大量の土砂が流出し，この区間の河道に約 600 万 $\mathrm{m}^{3}$ の土砂が堆積した．昭和36年より，国土交通省

（旧建設省）により支川で砂防堰堤の整備が進められ， 整備土砂量224万 $\mathrm{m}^{3}$ (整備率31\%) を確保してきている.

また，この区間に位置する関西電力の仙人谷ダム，小 屋平ダムは，それぞれ昭和15年，昭和11年に建設され， ほぼ満砂状態となっている.

\section{（3）ダム領域の土砂動態}

関西電力の出し平ダム (昭和60年完成) と下流の国土 交通省の宇奈月ダム（平成13年完成）では，ダム容量の 確保と下流への土砂供給を目的として, 洪水とともに土 砂を排出・通過する連携排砂・通砂を実施している.

ダム領域は，連携排砂・通砂を実施している2ダム河 川区間とその貯水池，並びに 2 ダム間とした. 出し平ダ ムの堆砂量は, 約 41 万 $\mathrm{m}^{3} /$ 年の排砂により約 20 万 $\mathrm{m}^{3} /$ 年に 留まっている. また, 宇奈月ダムの堆砂量は約66万 $\mathrm{m}^{3} /$ 年である.

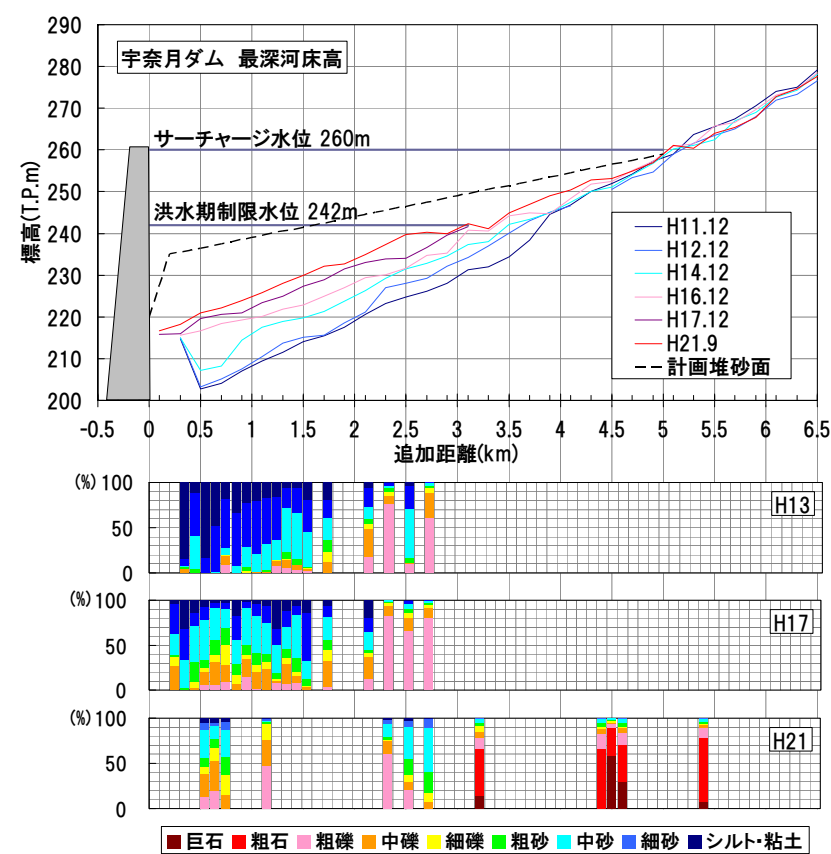

図-2 宇奈月ダム貯水池内の堆砂面と堆積土砂の粒度組成の変化
宇奈月ダムは，平成16年に堆砂面が土砂吐き敷高に達 し，それ以降堆砂速度は減少している，ただし，洪水期 制限水位（3k）付近では，堆積が進行している（図-2の 上図）。これは，貯水池に流入した土砂が掃流力の低下 により貯水池末端に堆積するためである.

宇奈月ダム貯水池内の堆積土砂の粒度組成をボーリン グ調査結果を基に分析した（図-2の下図）。平成13年は $1 \mathrm{k}$ から下流側はシルト・粘土分や細砂分がほとんどを占 めているが，堆砂面が土砂吐き敷高に到達した直後の平 成17年には中砂分の含有率が増大し，平成21年は更に粗 砂分や礫分等の粗い土砂の含有率の増大が見られる.

\section{（4）河道領域の土砂動態}

昭和26年以降の河床変動の時系列変化と年砂利採取量, 年最大流量を図-3に示寸.

愛本下流（0.0k～13.56k）では，昭和40年代～60年代 にかけて $1.5 \mathrm{~m} \sim 2.0 \mathrm{~m}$ の河床低下が進行した.この間，河 床低下区間（0.0k～13.56k）において年間 40 万〜 70 万 $\mathrm{m}^{3}$ の砂利採取等河道掘削が実施されており, 河床低下はそ の影響が極めて強いと考えられる，同区間では，平成以 降砂利採取を規制しており，河床は概ね安定傾向となっ ている. 愛本堰堤（13.56k）～宇奈月ダム（20.4k）では, 平成元年から平成 18 年で $0.8 \mathrm{~m}$ 程度河床低下している. こ の区間では, 昭和 60 年代以降最大約 10 万 $\mathrm{m}^{3} /$ 年の砂利採 取が実施されており, 河床低下の一因であると推定され る.

\section{（5）海岸領域の土砂動態}

海岸領域（境川〜片貝川）では，江戸時代以前の治水 事業による黒部川の現位置への固定化や漁港建設による 沿岸漂砂の遮断等の影響により海岸への供給土砂量が減 少し，海岸侵食が拡大した，漂砂は西向きであるから侵 食は東から西に向かって拡大し，概ね 50 年間で最大 $100 \mathrm{~m}$ 近く汀線が後退した。昭和46年以降護岸や離岸 堤・人工リーフ等による海岸侵食対策を実施しており, 汀線の後退は抑制されているが，現在，黒部川より東側

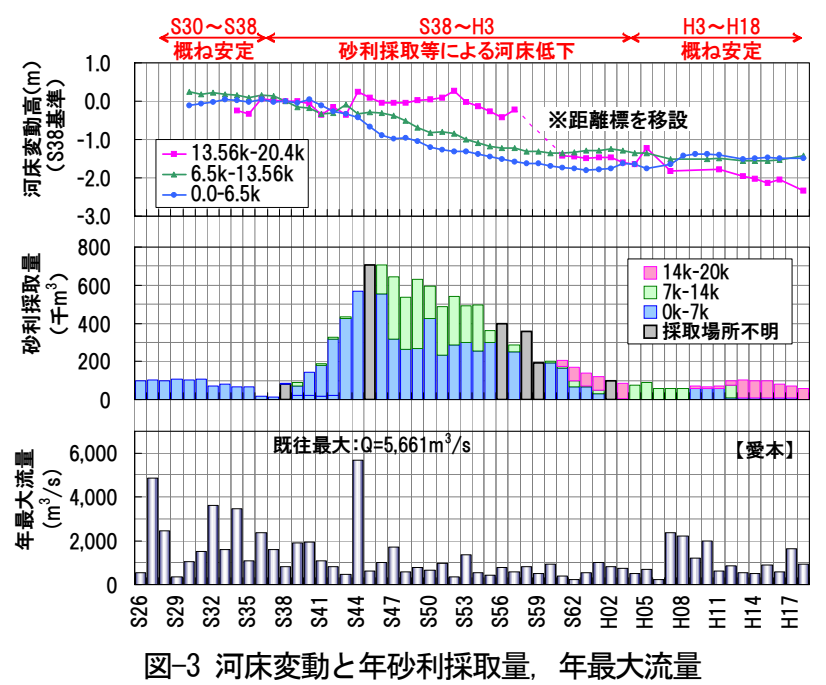



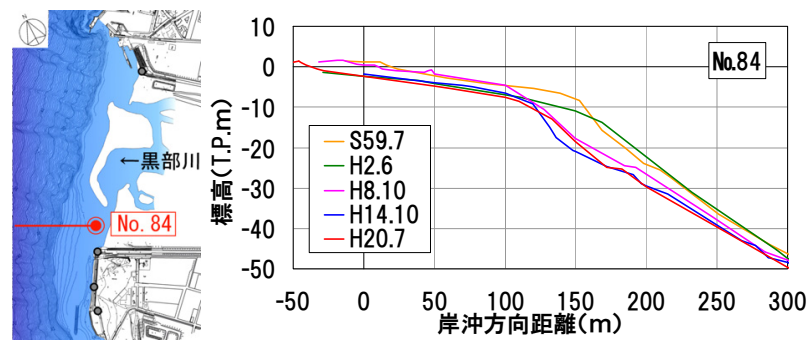

図-4 黒部川河口付近の海浜断面形状

の海岸では，漂砂が捕捉される海岸構造物の上手側（東 側）を除き，ほぼ砂浜が消失した状態となっている.

また, 海底勾配が $1 / 3 \sim 1 / 10$ と急な箇所も多く, 複雑な 海底地形による波の収劒のために生じる高波浪と相まっ て, 沿岸方向だけではなく, 沖方向への移動による土砂 損失が相当量生じている.

図-4に現在黒部川からの土砂供給の影響を受ける河口 左岸付近（No.84）の海浜断面の経年変化を示寸. 近年 は, 河口付近を中心に, 水深 $8 \mathrm{~m} \sim 20 \mathrm{~m}$ 程度の深い箇所で も岸向きに最大 $60 \mathrm{~m}$ 程度の侵食が認められる. 砂利採取 等河道掘削, ダムでの堆積等により黒部川からの土砂供 給が減少している可能性が考えられる. なお，平成14年 と比較し，平成20年では，汀線の回復傾向が認められる. これは連携排砂・通砂の効果によると推定される.

\section{3. 土砂動態解析モデルの構築}

\section{（1）モデル化の範囲と適用モデル}

黒部川流砂系の今後の土砂動態を把握するため, 土砂 の連続性が強い黒部ダム下流から河口と黒部川西側の海 岸を対象とした土砂動態解析モデルを構築した.

\section{a）砂防領域のモデルの概要}

黒部ダム下流から出し平ダム及び黒薙川の砂防領域 （本川，支川含む）は，急勾配での長期の土砂動態を表 現するため，山地区間の一次元河床変動モデルを用いた．
水理量は，等流計算による準定常とし，砂防堰堤等の影 響区間の水位は，越流公式により算定される水位で補完 している．流砂量は，掃流砂量式として芦田・高橋・水 山式 ${ }^{1)}$ (緩勾配式)，浮遊砂量式として芦田・道上式 ${ }^{2}$ を 適用し，限界掃流力はEgiazaroffの修正式》をを適用した.

\section{b）ダム領域のモデルの概要}

出し平ダムから宇奈月ダムのダム領域では, 貯水池内 の流れの非定常性や流砂の非平衡性が強く，土砂動態に 影響を与えることから，これらを考慮した一次元河床変 動モデル（ダム堆砂モデル）とした. 水理量は，不定流 計算とし，連携排砂・通砂時の水位低下，自然流下等に ついては，下流端水位を境界条件として与えた．流砂量 は，掃流砂量式として芦田・道上式 ${ }^{3)}$, 浮遊砂量式とし て芦田・道上式文を適用し，限界掃流力はEgiazaroffの修 正式了を適用した.

\section{c）河道領域のモデルの概要}

宇奈月ダムから河口の河道区間では，長期的な平均河 床高の変化及び流砂量を解析するため, 一次元河床変動 モデルとした. 水理量は，不等流計算による準定常とし， 流砂量は，掃流砂量式として芦田・道上式了)，浮遊砂量 として芦田・道上式泉を適用し, 限界掃流力はEgiazaroff の修正式了を適用した。

\section{d）海岸領域のモデルの概要}

海岸領域では，汀線及び海底の長期的な地形変化，沿 岸方向, 岸沖方向の漂砂量を解析寸るため, 沿岸漂砂量, 岸沖漂砂量及び混合粒径を考慮できる熊田 ${ }^{4}$ らの等深線 変化モデルを適用した．検討は，河川との土砂移動の連 続性が確認されている黒部川西側の海岸（河口〜片貝川 右岸)を対象としている.

なお，東側の海岸（右岸側）からの流入土砂量は，汀 線付近の沿岸漂砂が入善漁港でほぼ遮断されていること, 沖側では海底勾配が $1 / 3$ と急で，ほとんどの土砂が沖合 に流出すると仮定し, 流入流出なしの条件としている.

\section{表-1 再現計算条件}

\begin{tabular}{|c|c|c|}
\hline \multirow{5}{*}{$\begin{array}{c}\text { 砂 防 領 域 } \\
\text { (一次元河床変動計算 } \\
\text { (山地区間)) }\end{array}$} & 初 期 河 床 & 平成6年(黒薙川と不帰谷の一部は平成5年)測量値 \\
\hline & 河 床 材 料 & 線格子法(H11)実測值とサンプリング(H19)実測値の合成 \\
\hline & 生産土砂材料 & 支川黒薙川渓岸の粒度 (H20実測值)に，地山の細粒分 (H15実測値)を補間して作成 \\
\hline & 粗 度 係 数 & 黒部川本川 0.05 , 支川 0.06 と仮定 \\
\hline & 供給土砂量 & $\begin{array}{l}\text { 崩壊生産土砂量(継続崩壊地の表面侵食量;崩壊面積に平均侵食深 }(2.7 \mathrm{~m} / \text { 年;不帰 } \\
\text { 谷の実績)を乗じて算出) }\end{array}$ \\
\hline \multirow{4}{*}{$\begin{array}{l}\text { ダ ム 領 域 } \\
\text { (ダム堆砂モデル) }\end{array}$} & 初 期 河 床 & 宇奈月ダム 平成12年, 出し平ダム 平成12年の測量值 \\
\hline & 河 床 材 料 & $\begin{array}{l}\text { 宇奈月ダム }: \text { 平成21年(貯水池内は, H18,H19のボーリング調査結果) } \\
\text { 出し平ダム }: \text { 平成11年と平成19年実績值の合成 }\end{array}$ \\
\hline & 粗 度 係 数 & 0.03(貯水池内は0.04) と仮定 \\
\hline & ゲート操 作 & 連携排砂・通砂の操作実績 \\
\hline \multirow{4}{*}{$\begin{array}{c}\text { 河 道 領 域 } \\
\text { (一次元河床変動モデル) }\end{array}$} & 初 期 河 床 & 平成11年測量値 \\
\hline & 河 床 材 料 & 平成10年実績值(交換層,貯留層にそれぞれ表層,下層の調査結果を設定) \\
\hline & 粗 度 係 数 & $0.036 \sim 0.044(\mathrm{H} 7, \mathrm{H} 8$ 洪水の逆算粗度) \\
\hline & 砂 利 採 取 & 実績採取量を考慮 \\
\hline \multirow{5}{*}{$\begin{array}{c}\text { 海 岸 領 域 } \\
\text { (等深線変化モデル) }\end{array}$} & 初期等深線 & 平成13年測量值 \\
\hline & 底 質 材 料 & 平成20年実績值 \\
\hline & 移動限界水深 & T.P.+1.0m(陸側), T.P.-9.0m(沖側 $)^{5)}$ \\
\hline & 養 浜 & 実績養浜量を考慮 \\
\hline & 境界条件 & 西側:動的安定を仮定, 東側:流入流出なしと仮定 \\
\hline
\end{tabular}




\section{e）粒径の取り扱いとモデルの接続}

各モデルは，いずれも混合粒径での河床変動，等深線 変化モデルである，それぞれのモデルの粒径区分，計算 期間，計算ステップを統一し，流量及び土砂フラックス を共有することにより，砂防領域から海岸領域までを一 連のモデルとして構築した．また，混合粒径の取り扱い は，平野5)の交換層モデルとしている.

\section{（2）再現期間と計算条件}

土砂動態モデルの再現計算期間は，各領域に共通する データの存在状況, 宇奈月ダム建設等を考慮し, 平成13 年1月〜平成18年12月の6年間とした.

再現計算の条件を表-1にまとめて示寸．計算外力は, 砂防から河道領域は愛本（13.4k）の実績流量を元に比 流量で設定した. ただし，ダム領域については，実績流 入量，放流量を考慮している．また，海岸領域では，田 中観測所でのエネルギー平均波を与えた.

\section{（3）計算結果}

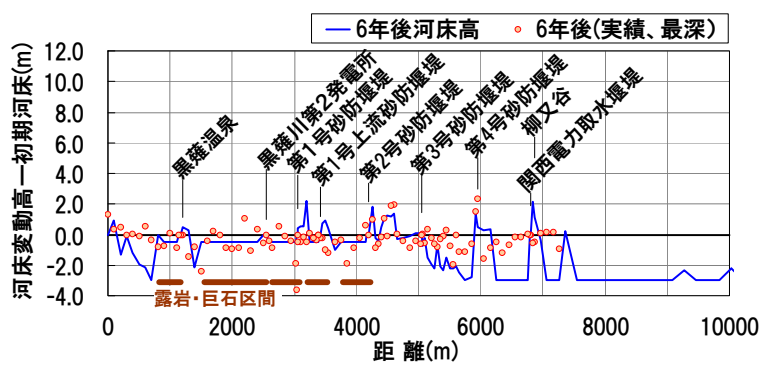

図-5 黒薙川の河床変動計算結果

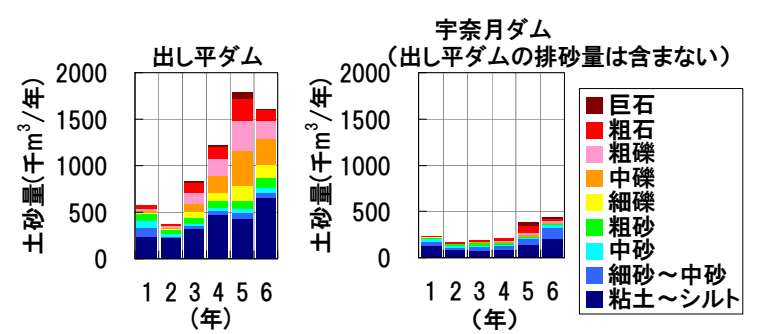

図-6 ダムへの流入土砂量の計算結果
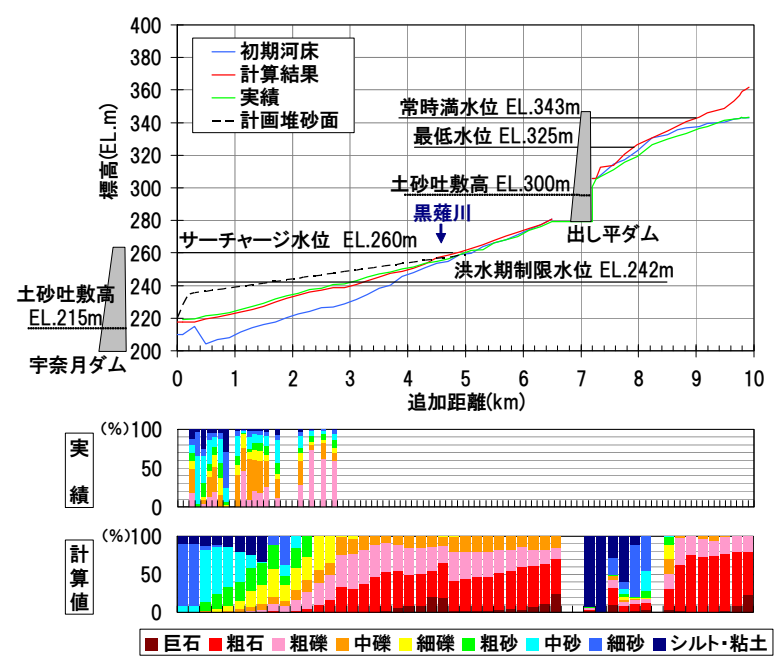

図-7 ダム領域の再現計算結果

\section{a）砂防領域}

砂防領域の計算結果のうち，黒薙川の河床変動計算結 果を図-5に示す．計算河床高は実測データに比べて変動 が大きく，土砂が動きやすいモデルとなっていると考え られる. 特に, 関西電力取水堰堤の下流, 柳又谷の上流 等では，実績に比べて計算河床高が低く算定されている． これは現地の露岩等の状況を十分に確認できていない箇 所であることから，露岩等による侵食下限高の設定，岩 塊状の大粒径土砂の移動状況やその遮蔽効果等の評価法 によるものと考えられる. 粒径毎の出し平ダムへの流入 土砂量, 宇奈月ダムへの流入土砂量（出し平ダムの排砂 量は含まない）の計算結果を図-6にそれぞれ示す。この 土砂量の妥当性は, ダム領域の再現性により確認寸る.

b) ダム領域

ダム領域の堆砂面及び河床材料の再現計算結果を図-7 に示寸，宇奈月ダムの堆砂面は概ね再現されており，堆 砂速度についても再現性を有していることを確認してい る.また，2.0k付近より下流区間において，実績に比べ 細磎分, 中礫分の割合が少なく, 中砂分が多くなる傾向 になるものの，堤体に向かって細粒化する傾向を概ね表 現している.

出し平ダムの堆砂面については十分な再現性が得られ ていないが，これはダム上流河道内での土砂移動のデー タが得られていないことに起因している. また，宇奈月 ダムの堆砂面, 堆砂速度, 粒度変化の傾向が概ね再現で きていることから，砂防領域からの供給土砂量は概ね妥 当な結果であると判断される，なお，砂防領域での粒径 毎の流出土砂量の解析精度が向上寸れば，ダム領域の河 床材料を含む解析結果の精度向上が期待できる.

\section{c）河道領域}

河道領域の河床変動計算結果を図-8に示す。河床変動 高は概ね再現されているが，河川工事等人為的な影響が 認められる区間では十分な再現性は得られていない。ま た，粒径毎の流砂量及び土砂収支の計算結果（図-9）を 見ると，細砂分以下の粒径は河道領域をほぼ通過してお

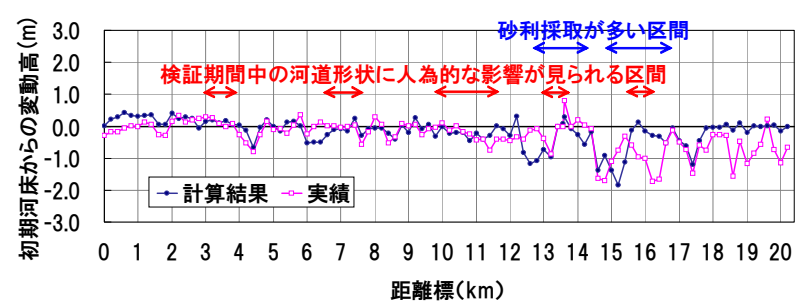

図-8 河道領域の河床変動計算結果

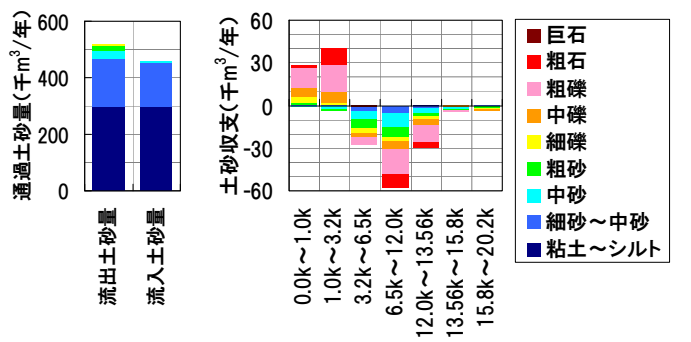

図-9 粒径毎の流砂量（左）及び土砂収支（右）の計算結果 
り，中砂分以上の粒径については，3.2k～13.5k区間で流 出傾向, $0.0 \mathrm{k} \sim 3.2 \mathrm{k}$ で堆積傾向となっている.

\section{d) 海岸領域}

図-10に汀線及び水深 $6 \mathrm{~m}$ の等深線の再現計算結果を示 す. 局所的には実績との乘離が見られるものの, 海浜変 化の傾向を再現している．沿岸漂砂量（図-11）は，平 均的に西向きに 1 万 $\mathrm{m}^{3}$ 年程度となっている. T.P. $-10 \mathrm{~m}$ 以 深への岸沖流出土砂量（図-12）は，河道領域からの供 給土砂量52万 $\mathrm{m}^{3}$ /年の内, 8〜9割が沖合へ流出する結果 が得られている。

\section{5. 土砂動態の動向の推定}

構築したモデルを用いて，今後の土砂動態の動向の推 定を行った。 なお，河川管理施設，海岸保全施設は現在 の施設が増減せず，同じ状態が100年間継続した場合を 想定した.

\section{（1）外力の設定}

流量は，土砂動態に寄与する出水発生の不特定性を考 慮するため, モンテカルロシミュレーションにより 100 年間の仮想降雨を発生させ，その降雨から貯留関数法に よる流出計算により算出した。

モンテカルロシミュレーションは，一次の自己回帰モ デルに季節変動を考慮したThomas-Fieringモデル7)を適用

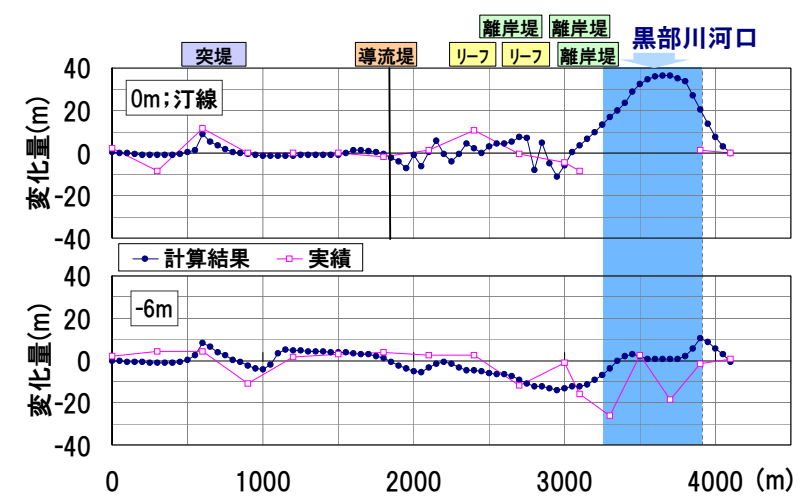

図-10 等深線の再現計算結果
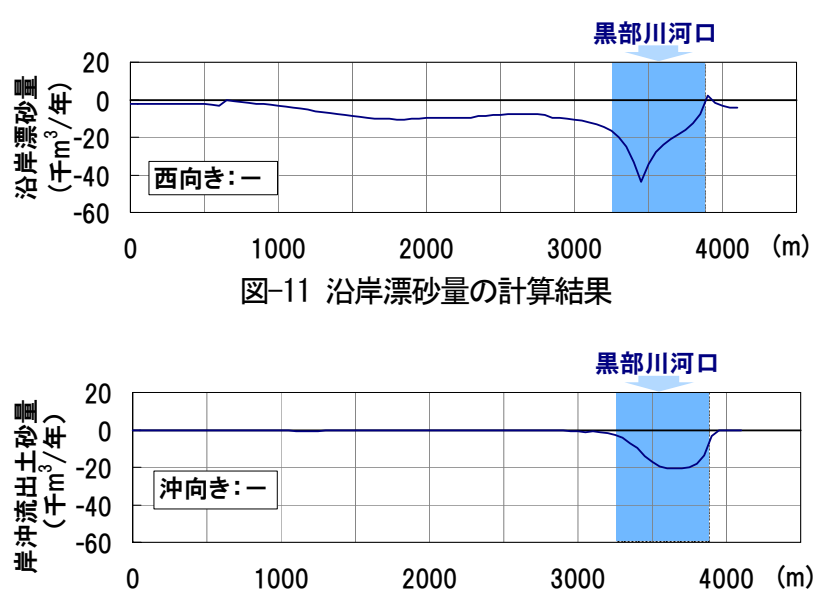

図-12 T.P. -10m以深への岸沖流出土砂量の計算結果
し，月最大降雨強度を発生させた．各降雨の波形は，月 最大降雨強度をもとに作成した中央集中型の降雨波形

（洪水到達時間 $1 \mathrm{hr} ，$ 降雨継続時間 $24 \mathrm{hr}$ ）とした。 なお, 仮想降雨は基本高水流量 $\left(7,200 \mathrm{~m}^{3} / \mathrm{s} ; 1 / 100\right)$ が100年間 に1回含まれるよう, トライアルにより発生させている.

波浪は，田中観測所での平成10年〜平成18年のエネル ギ一平均波を一定で与えた。

\section{（2）土砂動態の動向と課題}

河床高，河床材料等の初期条件は，それぞれ平成18年 時点としている. ただし, 平成18年の調査データが得ら れていないものについては，最も新しいデータを与えた。 a）砂防領域

境界条件について，生産土砂量は，新規・拡大生産土 砂量, 継続崩壊地表面侵食量を計上している。このうち, 新規・拡大生産土砂量は，崩壊予測式（平成7年出水の 崩壊実績加導出）から崩壊面積を算出し，平均崩壊深 (1.3m ; 平成7年出水実績) を乗じて算定した.

$$
Y=1.46 \times 10^{-7} \times(\mathrm{R}-\mathrm{r})^{2.747}
$$

ここに，Yは新規・拡大崩壊面積率 $(\%), \mathrm{R}$ は最大 24 時 間雨量 $(\mathrm{mm} / 24 \mathrm{hr}), \mathrm{r}$ は崩壊非発生雨量 $(=200 \mathrm{~mm} / 24 \mathrm{hr})$ である．新規・拡大崩壊面積率の上限は，実績の最大值 である祖母谷における $2.07 \%$ とした。他の条件は，再現 計算と同様とした.

この結果, 砂防領域から流入する土砂量は, 出し平ダ ム貯水池に 79.8 万 $\mathrm{m}^{3} /$ 年，宇奈月ダ ム貯水池に 20.7 万 $\mathrm{m}^{3} /$ 年（出し平ダムからの流入を除く）と推定される。これ は，宇奈月ダムの推定流入土砂量 140 万 $\mathrm{m}^{3} /$ 年に比べて, やや少ないもののほぼ妥当な值となっている.

\section{b) ダム領域}

砂防領域からの流出土砂量を境界条件として，ダム領

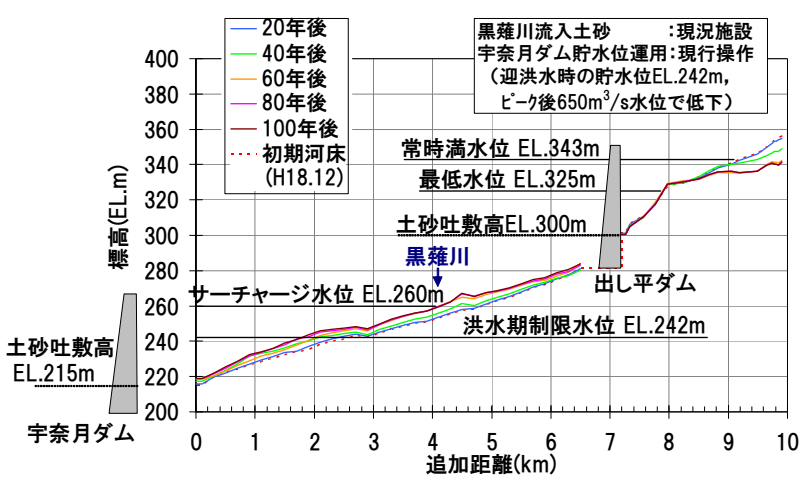

図-13 堆砂面の推定結果

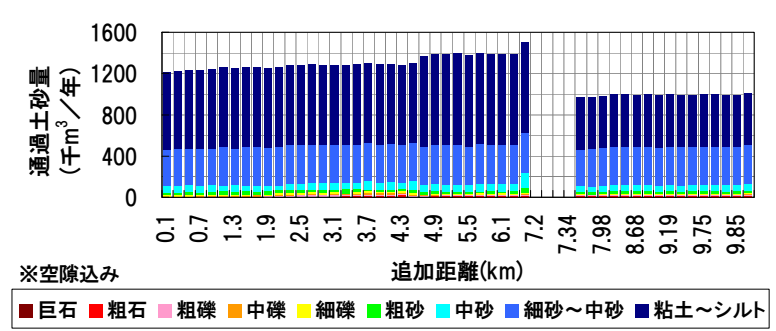

図-14 宇奈月ダムからの流出土砂量の推定結果 


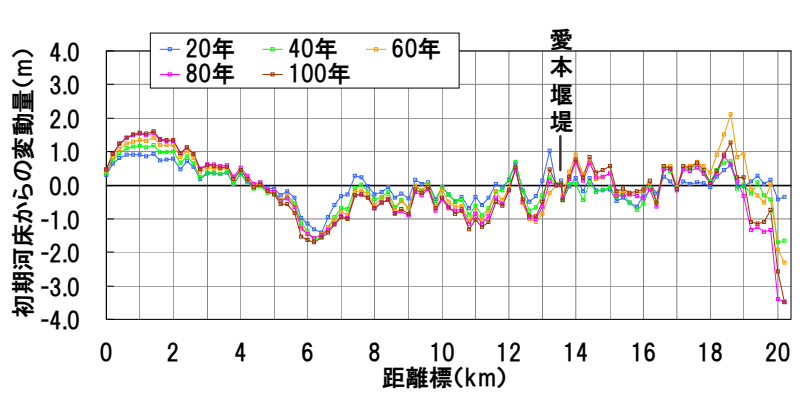

図-15 河床変動高の推定結果

域での土砂動態を推定した. 連携排砂・通砂の運用は, 現行の運用方法に準じ，宇奈月ダムにおける洪水前の水 位を洪水期制限水位（E.L.242m）とし，洪水低減時の流 量が $650 \mathrm{~m}^{3} / \mathrm{s}$ を下回った時点で水位低下を開始，自然流 下を12時間とした.

100 年間の堆砂面の変化及び宇奈月ダムからの流出土 砂量の推定結果を図-13，図-14にそれぞれ示す.

宇奈月ダム貯水池内の $22.4 \mathrm{~km}$ 付近（ダムサイトから $2 \mathrm{~km}$ 付近）を中心に，貯水池末端で㗂分（2.0mm〜 $75 \mathrm{~mm}$ ）以上の土砂による堆砂が進行する結果となった。 宇奈月ダムからの流出土砂量は, シルト・粘土分を含 めた全粒径で約 120 万 $\mathrm{m}^{3} /$ 年となっている. このうち, 細 砂分 $(0.075 \mathrm{~mm} \sim 0.25 \mathrm{~mm})$ 以上は 45 万 $\mathrm{m}^{3} /$ 年程度であり, 粗砂分 $(0.85 \mathrm{~mm} \sim 2.0 \mathrm{~mm})$ 以上の比較的粗い粒径は 2 万 $\mathrm{m}^{3} /$ 年程度（全体の約 $2 \%$ ） と少なくなっている. 下流河 道・海岸維持の観点から, 貯水池末端に堆積するような 粗い粒径の土砂の下流への供給など，質（粒径）に関し ても課題となる.

\section{c) 河道領域}

ダム領域からの流出土砂量を境界条件として, 河道領 域での土砂動態を推定した。 なお，砂利採取等河道掘削 は行わないと仮定した。

100年間の河床変動高及び粒径毎の流砂量, 土砂収支 の推定結果を図-15，図-16にそれぞれ示す。これらより， $5.0 \mathrm{k} \sim 7.0 \mathrm{k}$, 愛本堰堤（13.56k）下流や，20.0k付近では 河床低下傾向を示し, 川幅が広がり河床勾配が緩くなる 河口〜 4.0kや愛本堰堤〜 $19.0 \mathrm{k}$ では河床上昇傾向を示し ている．河床上昇区間では流下能力の減少，河床低下区 間では局所洗掘等による構造物への影響が懸念される.

河床低下区間では，石碩分の減少が顕著であり（図16），一層局所洗掘等を進行させる. 河床の上昇・低下 は一様でなく, 河道の安定性を確保するには，上下流を 通じた土砂量及び質（粒径）の評価・確保が課題となる。

\section{d）海岸領域}

100年間の汀線変化の推定結果を図-17に示寸. 河道領 域からの流出土砂量を境界条件として, 海岸領域の土砂 動態を推定した．なお，養浜は行わないと仮定した.

黒部川河口部及ひ現沖合消波施設（離岸堤，人工リー フ）設置区間（測点No.71〜No.81）までは堆積傾向（砂 浜の回復傾向）となる. それより西側の沖合消波施設の ない箇所では, 土砂流出の方が多く, 汀線の回復が進ま

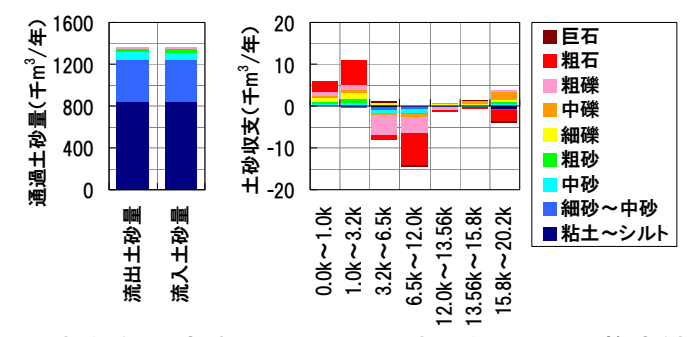

図-16 粒径毎の流砂量（左）と土砂収支（右）の推定結果

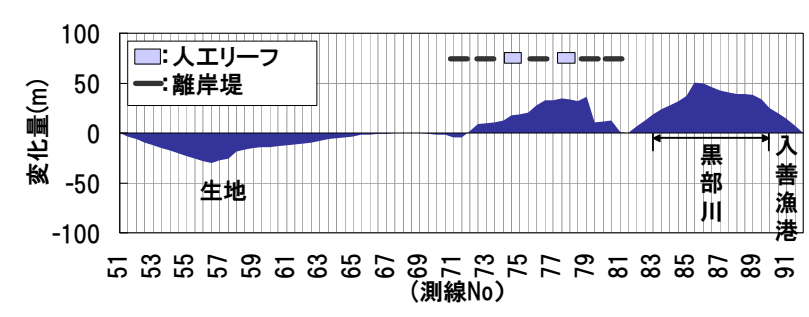

図-17 汀線変化の推定結果

ない結果となった。生地地区における砂浜回復の観点か ら，黒部川河口部及び現沖合消波施設設置区間に留まる 土砂が生地地区に到達するよう, 効果的な沖合消波施設 の設置・土砂管理が課題となる.

\section{6. おわりに}

黒部川流砂系における土砂動態について, 既往の調査 結果を示しながら連続した土砂動態モデルを構築して分 析を行った. 土砂動態を把握するために必要な資料が十 分存在しないことから，定量的な精度は必ずしも十分で はないが，課題，対策の方向性を明らかにすることがで きた. 今後, 関係する管理者の連携のもと総合的な土砂 管理を推進するとともに，必要なデー夕を補い，土砂移 動の連続性の確保等の状況を適宜把握しながら, 状況に 応じた適切な河川，海岸の管理を行って参りたい.

\section{参考文献}

1) 芦田和男·高橋保·水山高久 : 山地河川の掃流砂量に関寸る研 究, 新砂防, 第107号, pp. 9-17, 1978.

2) 芦田和男·道上正規 : 浮遊砂に関寸る研究 (I) - 河床付近 の濃度一, 京都大学防災研究所年報, 第13号B, pp. 63-79, 1970.

3) 芦田和男·道上正規 : 移動床流れの抵抗と掃流砂量に関する 基礎的研究, 土木学会論文報告集, 第206号, pp. 56-69, 1972.

4) 熊田貴之・小林昭男·宇多高明・芹沢真澄 : 沿岸・岸沖漂砂に よる粒径分級を考慮した等深線変化モデル, 海岸工学論文集, 第50巻, pp481-485, 2003.

5) 宇多高明 : 日本の海岸侵食, 山海堂, pp169-177, 1997.

6) 平野宗夫 : Armoringをともなう河床低下について, 土木学会 論文集, 第195号, pp.55-65, 1971.

7) 神田徹·藤田睦博 : 新体系土木工学 26 水文学 一確率的手 法とその応用一, 土木学会編, 技法堂出版, 1982

(2010. 9. 30受付) 